\title{
Clothes as Pseudo-Events: Ballyhoo, Rapture Bombs and Reginald Perrin
}

\author{
Barbara Brownie
}

\begin{abstract}
Empty bundles of clothes have the power to signify a variety of events, including voluntary undressing and forcible denuding. In empty clothes, the human body is notable in its absence, and the use of discarded shoes and garments in Holocaust memorials attests to their capacity to represent individual victims of large-scale tragedy. By representing absence through presence, clothes index the absent wearer, and invite speculation about the event that has separated body from garment. In a number of noteworthy events, ranging from Labour minister John Stonehouse's faked suicide (pseudocide) in 1974 to the 'rapture bombs' which littered the internet in the wake of predictions of the Rapture in 2011, abandoned clothes have been used to falsely signify tragedy. For the fictional anti-hero of David Nobbs' The Fall and Rise of Reginald Perrin (1975), undressing, and the planting of his empty clothes as false evidence, becomes the defining act of a complex act of deception, in which he fakes suicide and begins a new life under an assumed identity. This scene of 'pseudocide' has been recreated so many times that it is referred to colloquially as 'doing a Reggie Perrin'. This chapter will explore the role of abandoned clothes in what Daniel J. Boorstin describes as 'pseudoevents' - 'synthetic happenings' that are 'fabricated to make up for the world's deficiency'. 'It will examine how empty clothing is planted with the intention of fueling media speculation and to provoke the generation of false narratives, drawing on examples of promotional stunts in the 1920s, pseudocides in the 1970s, and rapture pranks in the 2010 s.
\end{abstract}

Key Words: Pseudo-events, Daniel J. Boorstin, clothes, The Fall and Rise of Reginald Perrin, rapture bomb, hoax, fake.

$* * * * *$

\section{Clothes and Pseudocide}

This chapter explores how clothes are used in deception, specifically, how an abandoned pile of clothes can play a pivotal role in large elaborate deceptions, such as pseudocide. Examples from fact and fiction illustrate how clothes can be used in the manufacturing of a pseudo-event, as in David Nobb's The Fall and Rise of Reginald Perrin (1975), and in the real life pseudocide of Labour MP John Stonehouse. Less elaborate hoaxes come in the form of so-called rapture-bombs, which, like pseudocides, use abandon clothes to signify the death or disappearance of the former wearer. 
David Nobb's tragi-comic novel The Fall and Rise of Reginald Perrin and the later BBC television adaptation of the same name (1976-1979) tell the tale of a frustrated salesman who fakes suicide by leaving his clothes and personal effects on Brighton beach. Perrin abandons his garments with the knowledge that those who find them are likely to assume that he has swum out to sea, never to return to shore. This scene of 'pseudocide' has been recreated in the real world so many times that it is referred to colloquially as 'doing a Reggie Perrin'.2

For those following in the footsteps of Stonehouse and Perrin, undressing can be a single gesture in a string of related actions that artificially construct a false event. Along with the formation of a false identity, undressing can be a vital step in the substitution of one identity for another: a means of killing off one's former self so that one may become someone else. This is, writes Michael Jay Lewis, 'a kind of non-corporeal suicide' which destroys 'that which has come to represent one's identity'. ${ }^{3}$

The everyday action of undressing and leaving clothes on the ground, in this case, is the abandonment of an identity, and so acknowledges the inextricable connection between clothes and the identity of the wearer. There is always 'personal or cultural meaning' in a garment left behind, and so matching a pile of clothing to its owner is not a difficult task, particularly when the owner has calculatedly selected clothing that is distinct. ${ }^{4}$

Perrin's plan, as described in Nobbs' novel, originally titled The Death of Reginald Perrin, is to 'go down to the south coast somewhere, leave his clothes in a neat pile on the beach' and start a new life under an assumed identity. ${ }^{5}$ As in many fictional 'disappearances into the sea', Perrin's actions do not represent death, rather, 'the sign that [he] will afterward be treated as dead by a given society'.

Reginald Perrin's pseudocide reflects 'the rise of the representation of pseudocide... in modern literature' as catalogued by Michael Jay Lewis. ${ }^{7}$ Lewis identifies examples including Hal Ashby's Harold and Maude (1971), in which Harold Chasen 'repeatedly stages his own death... in order to persist under another identity'. Lewis describes Chasen's pseudocides as acts of 'social recovery' and 'social evasion', motives which are also present in real-life instances of pseudocide. ${ }^{8}$

\section{2. 'Doing a Reggie Perrin'}

The opening credits of the BBC television adaptation depict the moment when Perrin removes his clothes. Perrin approaches from the distance, running parallel to the shoreline, clothed in a sombre suit. As he runs, he strips one garment at a time, tossing each in the direction of the sea, leaving a trail of clothing behind him. When he removes his final two garments - his shirt and underpants - he flings them aggressively, resolutely, determined to separate himself from these garments once and for all, and never to look back. Once naked, Perrin strides into the sea. 
Perrin does not enact his pseudocide until episode five of the first season. Nonetheless, this credit sequence appears from the very first episode, thereby presenting Perrin's undressing and his subsequent march towards the sea as the defining acts of the series. When the pseudocide is presented in the main narrative, it plays out differently. Perrin arrives at the beach in the dead of night, in a commandeered delivery truck. His walk along the pebble beach is languid and thoughtful. He carries a suitcase containing his disguise, on which he perches for a moment. As he stares out to sea, Perrin experiences a moment of doubt. He ponders a genuine suicide attempt. His internal monologue considers his shame at being labelled a fraud, and how much more effective a statement his suicide would make if it were genuine. He raises his arms in the air, and takes a few steps into the ocean, fully clothed. He stops suddenly when he feels the cold water lap at his ankles, and his doubts are suddenly erased. He dashes back onto the beach and all suggestions of genuine suicide are quickly forgotten.

This episode does not show Perrin undressing. The scene cuts to a shot of him donning the disguise that has been unpacked from his suitcase, including a false beard and overcoat. He bids goodbye to the pile of clothes that are now revealed to be resting at his feet, addressing them directly, and referring to his former identity in the third person, 'goodbye Reggie's clothes, goodbye Reggie'. His words reveal that the act of undressing has had personal significance for Perrin. As he sheds his clothes, he frees himself piece-by-piece from the tedium and frustrations of his former life. The suit has been a symbol of oppression throughout the series so far, and his former life is distinguished from the numerous identities that he adopts later through the means of a variety of alternative costumes. Shedding his suit, Perrin liberates himself from the restraints imposed by a single, fixed identity.

Perrin's enthusiasm is, however, far more subdued in this retelling of his pseudocide than it is in the opening credit sequence. The gusto with which he tosses his clothes on the beach in the credit sequence, which is by now familiar to viewers of the series, is absent from the acts as portrayed in episode five. The credit sequence depicts a daylight scene of gleeful undressing, in which Perrin's act is a celebration of his new freedom. This scene closely resembles Perrin's pseudocide as it is described in Nobbs' novel. In contrast, episode five depicts Perrin's pseudocide as a clandestine affair, carried out in the darkness, in which his feelings of doubt take precedence over his act of undressing. This version of events reveals the credit sequence is not, as viewers had no doubt assumed, a preview of Perrin's pseudocide. Instead, the sequence is revealed as symbolic of his bid for freedom. The daylight sequence is perhaps reflective of how Perrin imagines his pseudocide before reality intervenes.

Reginald Perrin's title sequence mythologises his pseudocide. His undressing on Brighton beach is constructed as the defining event of the series, despite its absence in the show's narrative. Thus, the myth of Perrin's actions is doubly false, 
being both fabricated (within the diegesis of Nobb's narrative) and misrepresented (to real-life viewers of the television show).

\section{Clothes as Decoys}

The writing of Nobbs' novel coincided with the real-life disappearance of British Labour politician John Stonehouse, who faked his own death in 1974, leaving a pile of clothes on Miami Beach. Stonehouse fled to Australia, where he was later tracked down. In the year of the premier episode of The Rise and Fall of Reginald Perrin, Stonehouse was jailed for seven years for fraud. ${ }^{9}$ Investigations revealed that pseudocide was just one of the many acts of deception that Stonehouse had carried out in order to transition from his former life to his new one. Stonehouse had adopted the alternative identity of Joseph Markham 'as a psychological safety valve' months before his supposed suicide. ${ }^{10}$ Like fictional equivalents, Stonehouse's actions allowed his 'ostensible demise while facilitating his ideological liberty ${ }^{\prime 1}$ : he stripped himself of the wardrobe of a failure in order that he might 'enjoy the feeling of being an honest man'. ${ }^{12}$

For Perrin and Stonehouse, abandoned clothes are decoys. Abandoning their clothes was the final public act in their genuine identities, and the visibility of this act is contrasted to the invisibility of the lives that they continued to lead after their pseudocide was complete. Thus, the novelty and apparent significance of their piles of clothes serves as a useful distraction, attracting attention to the clothes themselves, and away from the living bodies that once wore them.

Thanks to the prominence of these examples of clothing employed in pseudocide, audiences have not only became familiar with the notion that a pile of clothing signifies drowning, but also equipped with the knowledge that such a scene is easily faked. Armed with knowledge of these previous pseudocides, police have become alert to the suggestion that a pile of clothing may just as likely be evidence of a hoax than of a genuine death. North Carolina resident Robert Lee Battle failed in his attempt to convince the authorities of his suicide because his abandoned clothes revealed more than he had anticipated. Police became suspicious as a result of the objects missing from the pile of clothes that Battle left beside his abandoned truck on a bridge. ${ }^{13}$ The pile did not contain the most valuable parts of Battle's wardrobe, including those items which friends and family said were most precious to him - a voodoo charm and expensive wristwatch. Battle's decision to keep these items prompted a police investigation that later revealed the absence of a suit which Battle had reportedly stored in his tool shed. ${ }^{14}$

\section{Rapture Bombs}

Similarly misleading piles of clothes are arranged in order to index other events that have been widely mythologised but have never transpired. One such event is the Rapture. Depictions ranging from HBO's television series The Leftovers (2014) to Tim LaHaye and Jerry B. Jenkin's Left Behind novels (1995-2007) stress the 
significance of empty bundles of clothes as reminders of absent wearers. These piles of clothes provide survivors with tangible evidence that the Rapture has occurred, and a 'rebuke' to those who have been left behind.

Prompted by calculations made by Christian radio broadcaster Harold Camping, real-life believers in the Rapture anticipated a date of 21 May 2011 for the ascent of all deserving believers to heaven. When the Rapture failed to transpire on that date, pranksters were prompted to stage mock evidence in the form of piles of clothes evidently left behind as bodies ascended towards heaven.

These so-called 'Rapture bombs' - piles of clothes laid as false evidence of the sudden disappearance of the wearer - reflect both a desire to ridicule belief in the Rapture, and a need to compensate for the lack of occurrence of such a widely mythologised event. Historian Daniel J. Boorstin's exploration of America's insatiable desire for news observes a need to 'provide synthetic happenings to make up for the lack of spontaneous events'. We demand, he writes, 'more than the world can give us, we require that something be fabricated to make up for the world's deficiency'.

Such is the excitement of anticipation for some predicted events that if they fail to transpire, suggests Boortsin, there is a need to compensate with illusion. ${ }^{16} \mathrm{On}$ the day of 21 May 2011, as it became apparent that Camping's predictions were incorrect, photographs of 'rapture bombs' began to litter the web. These photographs inspired more elaborate fakery, including Capitol Improv's rapture prank video, staged at the Washington monument in 2011.

\section{Pseudo-Events}

Rapture bombs may be considered as a 'kind of synthetic novelty' that Daniel J. Boorstin describes as 'pseudo-events'. ${ }^{17}$ Pseudo-events, as defined by Boorstin, can be characterised by being planned, not spontaneous, 'planted... for the... purpose of being reported or reproduced', and having an ambiguous relationship to real events so as to invite speculation. ${ }^{18}$ The instigator's aim is to create a 'newsworthy' story, likely to provoke curiosity which will in turn generate speculation and prompt further reproduction.

One such pseudo-event is a ballyhoo - one of many 'loud, exaggerated, spectacular advertising stunts' that characterised 1920s media. Before the release of the silent horror film, A Blind Bargain (Wallace Worsley, 1922), New Jersey workmen discovered a mysteriously abandoned bundle of clothes lying on the bank of a canal in Newark. ${ }^{19}$ Police were called to investigate, and on inspection, officers discovered that the pocket of the abandoned jacket contained a cryptic note describing a 'blind bargain' evidently entered into by the previous wearer of the clothes. The note was signed 'Robert Sandell'. The discovery of the pile of clothes prompted a police investigation, and the mystery of Sandell's 'blind bargain' received front-page coverage in local press. Only when the film was released at local cinemas was Sandell revealed as the film's fictional protagonist. The bundle 
of clothes was revealed to have been laid as part of a promotional stunt intended to attract press attention in the run up to the cinematic release. Lyczba lists this as just one of numerous paratextual stunts that bridge the divide between fact and fiction, making use of concrete objects to 'play on the public's sense of what is real, or what is not'. ${ }^{20}$

These pseudo-events rarely exist in isolation. The abundance and variety of rapture bombs online evidences Boorstin's suggestion that 'pseudo-events spawn other pseudo-events'. ${ }^{21}$ They can be 'repeated at will, and thus their impression can be reinforced. ${ }^{22}$ A style of hoax becomes 'ritualized, with a protocol and a rigidity all its own'. ${ }^{23}$ A language emerges, laying out rules for the staging of a particular form of pseudo-event: for rapture bombs, the rules dictate an arrangement of clothing that imitates the form of the absent body in an everyday location such as a home or park; for pseudocide, the ritual of undressing must ensure that clothes are discovered close to a body of water (since death by drowning would provide justifiable reason for the lack of a body). As these rituals become familiar they are more frequently duplicated. In the decades that have followed Perrin and Stonehouse's deceptions, they have inspired numerous imitators, including Lincolnshire dockmaster Graham Cardwell, who began a new life under an assumed name after leaving his lifejacket and helmet on mud flats in $1998 .{ }^{24}$

As each type of pseudo-event acquires this rigidity, pressures arise to produce other, derivative, forms of pseudo-event which are more fluid, more tantalizing and more interestingly ambiguous'. ${ }^{25}$ Rapture bombs have evolved from simple piles of clothing to dynamic arrangements of garments and props which appear to suggest that the raptured soul has unexpectedly vanished while in the middle of some kind of activity. Capitol Improv's staged Rapture video demonstrates how rapidly rapture bombs developed into sophisticated 'rapture skits'. Pseudocides have evolved too, with more recent examples featuring additional fabricated evidence such as bloodstains on the clothes, as was the case with the presumed pseudocide of salesman Andrew Hoy, whose blood-stained clothes were found inside his abandoned BMW in Essex in 1999. ${ }^{26}$

With each new example, audiences become more familiar with the intended meaning of the staged scene, and this familiarity allows pranksters or fraudsters to make their scenes more elaborate and ambiguous. Thus, the audience's role in interpreting the scene becomes essential. Whenever clothes are falsely presented as evidence, they are arranged with the awareness that they will be read by whoever finds them. 'Isolated clothes create for us a mystery we must solve'. ${ }^{27}$ Like most pseudo-events, they prompt a blurring of the roles of actor and audience, in which those who witness false evidence become unwittingly complicit in 'generating an event'. ${ }^{28}$ Rapture bombs are arranged so as to invite the viewer to imagine in great detail the moment of Rapture, and are reliant on peer-to-peer distribution of the image to expand the audience. Reginald Perrin, John Stonehouse, and other perpetrators of pseudocide undress with the sole aim of creating false evidence, 
that is, they are 'planned for dissemination'. ${ }^{29}$ Those who found Stonehouse's pile of clothing became unknowingly complicit in his deception, by offering a particular interpretation of the clothes as evidence.

\section{Notes}

${ }^{1}$ Daniel J. Boorstin, The Image: A Guide to Pseudo-Events in America, First Vintage Books Edition (New York: Vintage, 1992), 9.

2 'Pseudocide: Doing a Reggie Perrin', BBC News, 14 February 2000, viewed 15 October 2014, http://news.bbc.co.uk/1/hi/uk/639098.stm.

${ }^{3}$ Michael Jay Lewis, “Am I Not Really Dead?" Pseudocide, Individuation, and the Fictional Awakening', Literary Imagination 16.3 (2014): 346.

${ }^{4}$ Jeff Smith, 'The Sound of Intensified Meaning', The Oxford Handbook of New Audiovisual Aesthetics, eds. John Richardson, Claudia Gorbman and Carol Vernallis (Oxford: Oxford University Press, 2013), 331-356.

${ }^{5}$ David Nobbs, The Death of Reginald Perrin: A Novel [later reissued as The Fall and Rise of Reginald Perrin] (London: Gollanz, 1975), 113.

${ }^{6}$ Lewis, “"Am I Not Really Dead?”, 350.

${ }^{7}$ Ibid., 346-348.

${ }^{8}$ Ibid., 348.

9 'MP Planned Death for Months', BBC News, 29 December 2005, viewed 29 January 2015, http://news.bbc.co.uk/1/hi/uk politics/4564226.stm.

10 'John Stonehouse, 'Shed His Guilt by Adopting New Identity', The Telegraph, 29 December 2005, viewed 29 January 2015,

http://www.telegraph.co.uk/news/uknews/1506526/John-Stonehouse-shed-hisguilt-by-adopting-new-identity.html.

${ }^{11}$ Lewis, “"Am I Not Really Dead?" 350.

12 John Stonehouse, 'Shed His Guilt by Adopting New Identity', The Telegraph, 29 December 2005, viewed 29 January 2015, http://www.telegraph.co.uk/news/uknews/1506526/John-Stonehouse-shed-hisguilt-by-adopting-new-identity.html.

'Elaborate Suicide Hoax Foiled by Bondsman', Times-News, Hendersonville, N.C., 29 June 1982, 10, viewed 20 December 2014, http://news.google.com/newspapers?nid=1665\&dat=19820629\&id=O2AaAAAAI BAJ\&sjid=zSQEAAAAIBAJ\&pg=6455,8097717.

14 'Suicide Hoax Didn't Work', The Dispatch, Lexington, N.C., 30 June 1982. 22, viewed 20 December 2014, http://news.google.com/newspapers?nid=1734\&dat=19820630\&id=wuYbAAAAI BAJ\&sjid=11IEAAAAIBAJ\&pg=4610,9453646.

${ }^{15}$ Boorstin, The Image, 9.

${ }^{16}$ Ibid.

${ }^{17}$ Ibid. 
${ }^{18}$ Ibid., 11.

19 'Blind Bargain Victim Brings Space in Newspapers', Motion Picture News, 23 December 1922.

${ }^{20}$ Fabrice Lyczba, "“The Living Realities of Romance": Playing with the Illusion of Reality in 1920s Film Reception Paratexts' (Paper presented at Media Mutations 5, 21-22 May 2013, Universita di Bologna).

${ }^{21}$ Boorstin, The Image, 33.

${ }^{22}$ Ibid., 39.

${ }^{23}$ Ibid., 33.

24 “"Reggie Perrin” Father Escapes Punishment', BBC News, 8 June 1999, viewed 26 December 2014, http://news.bbc.co.uk/1/hi/uk/364379.stm.

${ }^{25}$ Boorstin, The Image, 33.

${ }^{26}$ Leonard Rossiter, 'Real Reginald Perrin Incidents', Reggie Online: The Official Reginald Perrin Website, 2004, viewed 29 December 2014, http://www.leonardrossiter.com/reginaldperrin/Real.html.

27 Jude Tallichet, 'Six Features', Jude Tallichet Studio, 2014, viewed 17 April 2015, http://judetallichetstudio.com/index.php?/press-release/six-features/.

${ }^{28}$ Boorstin, The Image, 29-30.

${ }^{29}$ Ibid., 39.

\section{Bibliography}

'Blind Bargain Victim Brings Space in Newspapers'. Motion Picture News, 23 December 1922.

Boorstin, Daniel. J. The Image: A Guide to Pseudo-Events in America. First Vintage Books edition. New York: Vintage, 1992.

'Elaborate Suicide Hoax Foiled by Bondsman'. Times-News, Hendersonville, N.C., 29 June 1982. Viewed 20 December 2000.

http://news.google.com/newspapers?nid $=1665 \& \mathrm{dat}=19820629 \& \mathrm{id}=02 \mathrm{AaAAAAI}$ BAJ\&sjid=zSQEAAAAIBAJ\&pg=6455,8097717.

'John Stonehouse. Shed His Guilt by Adopting New Identity'. The Telegraph, 29 December 2005. Viewed 29 January 2015.

http://www.telegraph.co.uk/news/uknews/1506526/John-Stonehouse-shed-hisguilt-by-adopting-new-identity.html.

Lewis, Michael Jay. ““Am I Not Really Dead?” Pseudocide, Individuation, and the Fictional Awakening'. Literary Imagination 16.3 (2014), 344-365. 
Lyczba, Fabrice. "“The Living Realities of Romance": Playing with the Illusion of Reality in 1920s Film Reception Paratexts'. Paper presented at Media Mutations 5, 21-22 May 2013, Universita di Bologna.

'MP Planned Death for Months'. BBC News, 29 December 2005. Viewed 29 January 2015. http://news.bbc.co.uk/1/hi/uk politics/4564226.stm.

Nobbs, David. The Death of Reginald Perrin: A Novel [later reissued as The Fall and Rise of Reginald Perrin]. London: Gollanz, 1975.

'Pseudocide: Doing a Reggie Perrin'. BBC News, 14 February 2000. Viewed 15 October 2014. http://news.bbc.co.uk/1/hi/uk/639098.stm.

“"Reggie Perrin” Father Escapes Punishment'. BBC News, 8 June 1999. Viewed 26 December 2014. http://news.bbc.co.uk/1/hi/uk/364379.stm.

Rossiter, Leonard. 'Real Reginald Perrin Incidents'. Reggie Online: The Official Reginald Perrin Website, 2004. Viewed 26 December 2014. http://www.leonardrossiter.com/reginaldperrin/Real.html.

Smith, Jeff. 'The Sound of Intensified Meaning'. The Oxford Handbook of New Audiovisual Aesthetics, edited by John Richardson, Claudia Gorbman and Carol Vernallis, 331-356. Oxford: Oxford University Press, 2013.

'Suicide Hoax Didn't Work'. The Dispatch, Lexington, N.C., 30 June 1982. Viewed 20 December 2014.

http://news.google.com/newspapers?nid=1734\&dat=19820630\&id=wuYbAAAAI BAJ\&sjid=11IEAAAAIBAJ\&pg=4610,9453646.

Tallichet, Jude. 'Six Features'. Jude Tallichet Studio, 2014. Viewed 17 April 2015. http://judetallichetstudio.com/index.php?/press-release/six-features/.

Barbara Brownie is a senior lecturer in Visual Communication at the University of Hertfordshire, and leader of the Deception project. 